\title{
Time Management Skills and Student Performance in Online Courses
}

\section{Prof. Susan L. Miertschin, University of Houston (CoT)}

Susan L. Miertschin, M.Ed., M.S.I.S., is an Associate Professor teaching in the Computer Information Systems program at University of Houston. Her teaching interests are in the areas of (1) information systems applications development and the complementary nature of back-end developer and front-end developer skill sets and (2) managing IT services. Her research interests are program and student assessment, the impact of instructional technology on student learning, and the improvement of e-learning environments and experiences.

\section{Dr. Carole E. Goodson, University of Houston (CoT)}

Carole Goodson is a Professor of Technology at the University of Houston. As an active member of ASEE, she is a member of the Academy of Fellows, a past Editor of the Journal of Engineering Technology, a past Chair of PIC IV and the ERM Division, and a past Chair of the Gulf Southwest Section of ASEE.

\section{Dr. Barbara Louise Stewart, University of Houston}

Barbara L. Stewart is a Professor of Retailing and Consumer Science at the University of Houston. Her teaching and research interests are in the application of strategies to improve student learning and life enhancement in online courses. She has served as an academic administrator and in leadership positions for numerous professional organizations. 


\section{Time Management Skills and Student Performance in Online Courses}

As educators, we have the almost daily task of turning students' goals into the reality of completed degrees. In part, we accomplish this by requiring students to spend time with course content. Students, in turn, must plan and use their time effectively in order to accomplish course goals and objectives. Online courses present special challenges for student engagement and effective time management; thus, effective course design built on an understanding of the nature of time management in an academic setting is essential for faculty designing the courses.

The authors' path to the current study began with investigation related to online instruction and learning followed by several more investigations that considered issues of time management. The authors first considered which elements of online course delivery were perceived by students to be valuable ${ }^{1}$. In a subsequent study the authors found that students believed they learned to manage their time from participation in online courses ${ }^{2}$. Another study revealed that specific course features included in the design of online courses were both used by students and perceived as beneficial to students with respect to their management of time ${ }^{3}$. The study reported here focuses more specifically on relationships among students' self-reported time management behaviors, demographic characteristics of the students, course format (online versus face-toface), and perceived use of particular course elements. The paper addresses the following issues.

- Are there identifiable characteristics of students who are proficient (as indicated by their TM scores) in specific time management skills?

- Are these time management skills related to student use of course design features?

- What are some of the specific time management strategies that are utilized by students?

\section{Concepts of Time Management}

Driven by a need for increased productivity, managing time has received attention from researchers for decades. Scientific approaches to the issue emerged as early as 1913 when Frederick Taylor, a mechanical engineer, published The Principles of Scientific Management ${ }^{4}$. His work spawned techniques that used careful study and analysis of business and production processes to determine the one "correct", most efficient way to perform each component task so that workers might be trained to standards of efficiency. More human-centered approaches to the issue arose from psychology (and related fields) that sought to support and motivate the worker to complete his/her expected tasks on time and within budget ${ }^{5-7}$. In the field of education, researchers have recognized the importance of relationships between students' ability to manage their time effectively and their academic success, and so research has been conducted in this arena as well ${ }^{8-11}$. Each body of research viewed issues of time management from different perspectives.

For some researchers, control of time was the major theme. For example, Macan ${ }^{12}$ tested a process model of time management and concluded that the major outcome of engagement in time management behaviors was perceived control of time. Eilam and Aharon ${ }^{10}$ saw time management as a way to monitor and control time. For others, time management focused on the use of time, including use of time as structured and purposive ${ }^{5,13-15}$, gaining insight into time 
use $^{16}$, and planning and allocating time ${ }^{6,17}$. Additionally, some authors focused on techniques for managing time ${ }^{12,18-22}$, while others viewed time management as a process of self-regulation, goal setting, or prioritizing ${ }^{23-25}$ or as a means to mitigate stress or achieve life balance ${ }^{19,26,27}$.

More specific to online learning environments, Shepperd ${ }^{28}$, while investigating student time management in distance education, found time management to be a predictor of student success. Relationships were noted for specific time management skills, ability to balance multiple roles, pacing ability, self-direction, and quality of work. Furthermore, students who were able to prioritize time commitments experienced great success. Conversely, poor time management was given as a reason for dropping distance education courses. Similarly, procrastination was found to yield a negative impact on completion.

The research review showed mixed results for whether instructional design can influence a student's ability to manage her time and whether time management skills can be taught. While multiple authors ${ }^{29-34}$ contended that skills to support time management can be taught and learned, studies by Slaven and Totterdell ${ }^{20}$ and Macan $^{35}$ did not find that time management training improved time management practices. In fact, work by Claessens ${ }^{36}$ reviewed eight studies where the results of time management training were mixed, showing both improvement and no improvement. Yet, many studies did report a positive relationship between time management training and subsequent time management behaviors ${ }^{12,18,20,30,33}$. Numerous studies of college students indicated a direct link between time management skills and academic performance $^{9,10,19,37}$.

\section{Study Procedures}

One hundred ninety-one students at the University of Houston were surveyed in 2014 in order to explore relationships between students' time management skills and the course features of online versus face-to-face courses. The research aimed to obtain a clearer understanding of the elements that are associated with a student's ability to manage time effectively in order to successfully complete courses.

Students enrolled in five courses that varied in subject, level, and delivery mode elected to complete the survey. All courses included an online course interface delivered though a common course management system, Blackboard Learn. Online courses used the Blackboard Learn interface as the exclusive delivery system for the course, while face-to-face and hybrid courses used the interface to supplement traditional in-person course delivery and management practices.

Table 1: Courses Used for Survey Administration

\begin{tabular}{|l|l|l|}
\hline \multicolumn{1}{|c|}{ Course } & \multicolumn{1}{c|}{ Level } & \multicolumn{1}{c|}{ Format } \\
\hline Integrated Information Systems & Upper division (junior) & Hybrid \\
\hline Database Administration and Implementation & Upper division (senior) & Face-to-Face \\
\hline Research Concepts in HDCS & Upper division (senior) & Online \\
\hline Visual Merchandising & Upper division (junior) & Online \\
\hline Data Analysis & Graduate & Online \\
\hline
\end{tabular}


While the courses through which students completed the survey included face-to-face, hybrid, and online formats, the survey questions were directed at the students' overall experience with online courses, as opposed to their experience with the particular course in which they were surveyed. Thus, more relevant than the course in which the student was enrolled is the amount of personal experience the students had with online courses. Seventy three percent of the participants had completed four or more online courses and 93\% of the students had completed at least one online course while enrolled at the University. Thus, the respondents had significant experience with online learning environments for coursework.

The survey was implemented through the assessment module of Blackboard Learn so that it could be delivered in an online format likely to be familiar to the students. Students were assured that completion of the survey was voluntary and that all responses would be anonymous to the instructor and the researchers and would remain anonymous upon publication of any results. The students were instructed to answer the questions with respect to their college learning experiences, in general, and not with respect to the specific course that delivered the survey. Student responses were downloaded for analysis; each response record was identified by a number assigned by the learning management system that was used to deliver the survey.

The survey instrument was adapted from an instrument used in a previous study by the authors ${ }^{3}$. Specific items designed to address the specialized goals of this research were added. The survey instrument consisted of fifty-two items. The first section addressed student demographic characteristics including: 1) student classification (freshman, sophomore, etc.), 2) number of online courses completed, 3) enrollment status (mostly full-time or mostly part-time), 4) age, 5) estimated overall GPA, 6) employment status, 7) current enrollment (number of semesters credit hours), and 8) major.

A second part of the survey was concerned with instructional components or features of online courses. Components were selected for investigation based on: 1) the researchers' collective experience with particular components widely used in online courses and 2) responses to a previous survey regarding time management ${ }^{3}$. This component of the survey presented a list of 10 course features, to which students responded with frequency of use for each feature, i.e. daily, weekly, monthly, semester, or not used. The course features included orientation materials, course calendar, course requirements description, objectives, course content (in any format), discussion boards, email with the instructor, instructor notices, on campus office hours, and online office hours.

An embedded cluster of items toward the end of the survey is the primary focus of this paper. Based on this grouping of items, each participating student was assigned a Time Management (TM) score. Collectively these items measured the extent to which students engaged in time management practices perceived to be effective by the body of knowledge about time management. Specifically, the TM score included the practices of: 1) using a time-based planner or calendar to schedule time for course study and homework, 2) scheduling to complete longterm assignments over time, 3) study routines, 4) study schedules, 5) study sessions before a test, and 6) a general organized plan for study of course material.

The reliability of this group of items was assessed using Cronbach's alpha which yielded a reliability coefficient of $\alpha=0.84$. This value suggests that the items have high internal 
consistency. Note that a Cronbach's alpha value of 0.70 or higher is generally considered acceptable in social science research for establishing reliability ${ }^{38}$.

For the students surveyed, TM scores ranged in value from a low of 18 to a high of 70 with a mean of 50, a standard deviation of 11.7, and a median of 51. The Coefficient of Skewness of the data was 0.48 which suggests that the distribution of this sample is approximately symmetrical (because the coefficient is between -0.5 and 0.5$)^{39}$.

Student responses to the survey items described were tabulated; tables, graphs, and descriptive measures were used to analyze the data.

Finally, open-ended questions were presented in the survey to further explore the students' concept of time management and how it interacts with course success in online and face-to-face courses. The open-ended responses were analyzed using the standard text analysis method of keyword extraction followed by tabulation.

\section{Study Results}

The analysis was designed to consider the following issues.

- Are there identifiable characteristics of students who are proficient (as indicated by their TM score) in time management skills?

- Are these time management skills related to student use of online course design features?

- What are some of the specific time management strategies that are utilized by students?

Ninety-five percent of the participating students were classified as at least juniors, and thus, were experienced students. The students were also experienced with online courses; $73 \%$ of them had completed at least four online courses, and only $4 \%$ had completed zero or one online course. The students were otherwise characterized as under 30 years of age (92\%) and employed, either in a full-time or part-time position (75\%), with a GPA greater than 2.50 (92\%). More of the students who completed the survey attended school mostly part-time as opposed to mostly fulltime.

Time Management scores (TM) were analyzed by classifying the score as Low or Strong. To obtain this classification, a z-score was computed for each score. A z-score below -1 was classified as low, between -1 and 0 was classified as moderately low, between 0 and 1 was classified as moderately strong, and a z-score greater than 1 was classified as strong. To further summarize and compare results, the scores were combined further, with low and moderately low scores represented as Low and moderately strong and strong listed as Strong. Hence, negative zscores were classified as Low and positive z-scores were classified as Strong. With these classifications, comparisons of percent of students with Low versus Strong time management scores were made based on several demographic variables using contingency tables (based on percentage of row total). The demographic variables that were considered include: number of completed online courses, enrollment status, age, self-reported grade point average (GPA), and employment. 
Tables 2 through 6 and the corresponding Figures 1 through 5 show a comparison of TM score classifications based on demographic information including the number of completed online courses, enrollment status (mostly full time vs. mostly part time), age category, grade point average (GPA), and employment status (full-time, part-time, not employed).

Table 2 Time Management Classification by Number of Online Courses

\begin{tabular}{|l|rr|r|r|}
\hline & \multicolumn{2}{|c|}{ TM Score Classification } & & \\
\hline No. OL Courses & Low TM Score & Strong TM Score & Total & n \\
\hline $0-1$ & $54 \%$ & $46 \%$ & $100 \%$ & 13 \\
$2-3$ & $55 \%$ & $45 \%$ & $100 \%$ & 38 \\
4 or more & $43 \%$ & $57 \%$ & $100 \%$ & 140 \\
\hline Total & $46 \%$ & $54 \%$ & $100 \%$ & 191 \\
\hline
\end{tabular}

Figure 1 Time Management Classification by Number of Online Courses

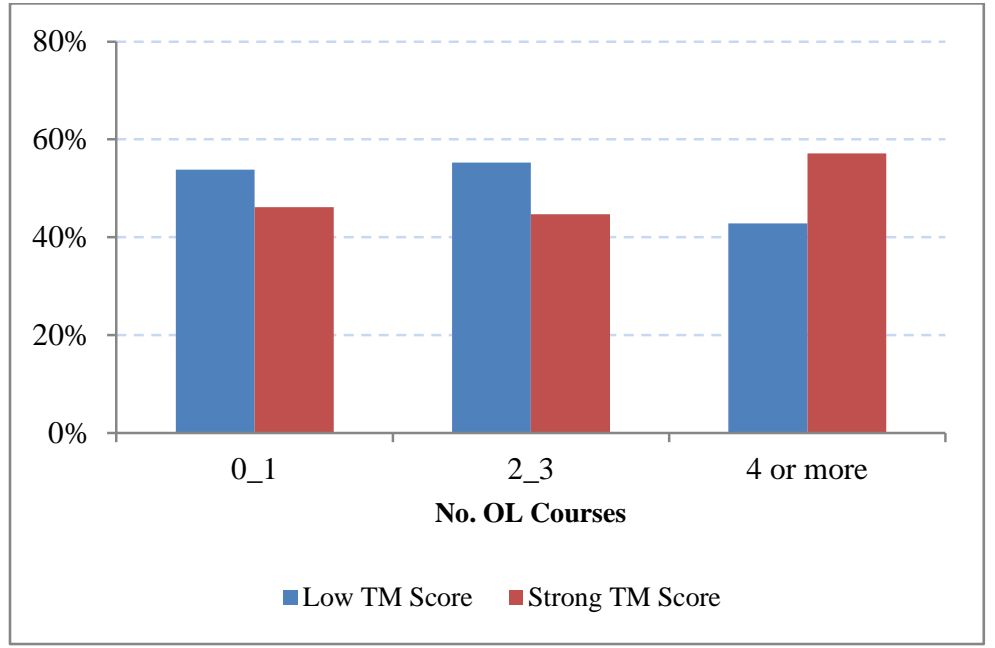

$(n=191)$

Table 3: Time Management Classification by Enrollment Status

\begin{tabular}{|l|rr|r|r|}
\hline & \multicolumn{2}{|c|}{ TM Score Classification } & & \\
\hline Enrollment & Low TM Score & Strong TM Score & Total & $\boldsymbol{n}$ \\
\hline Mostly full-time & $46 \%$ & $54 \%$ & $100 \%$ & 164 \\
Mostly part-time & $44 \%$ & $56 \%$ & $100 \%$ & 25 \\
\hline Grand Total & $46 \%$ & $54 \%$ & $100 \%$ & 189 \\
\hline
\end{tabular}

( $\mathrm{n}=189 / 2$ NR not included) 
Figure 2: Time Management Classification by Enrollment Status

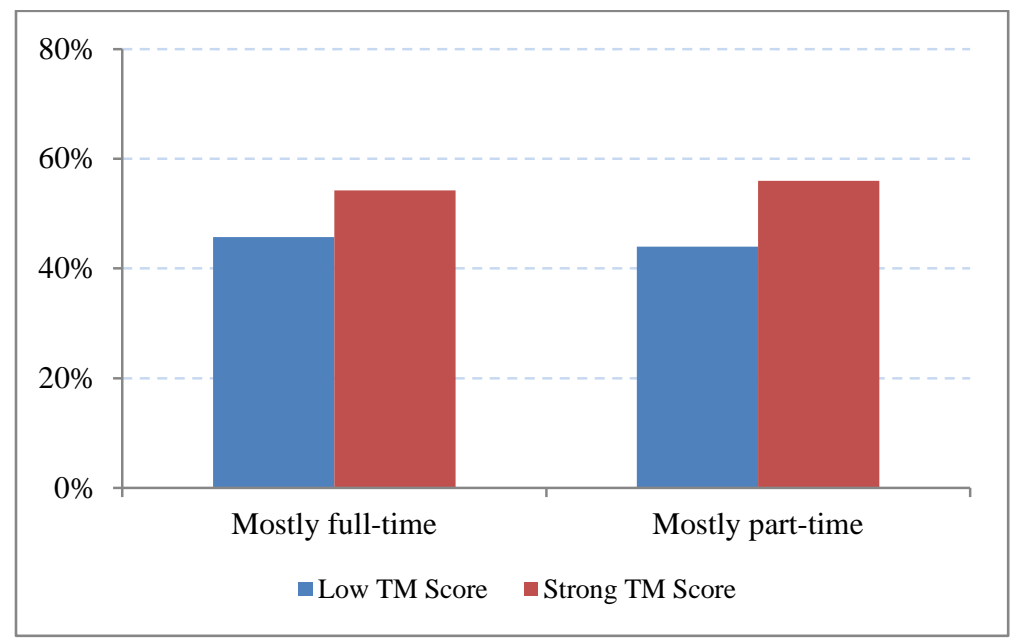

$(n=189)$

Table 4: Time Management Classification by Age Category

\begin{tabular}{|l|rr|r|r|}
\hline & \multicolumn{3}{|c|}{ TM Score Classification } & \\
\hline Age & Low TM Score & Strong TM Score & Total & $\boldsymbol{n}$ \\
\hline$\leq 20$ years & $44 \%$ & $56 \%$ & $100 \%$ & 30 \\
$21-25$ years & $49 \%$ & $51 \%$ & $100 \%$ & 58 \\
26 - 30 years & $49 \%$ & $51 \%$ & $100 \%$ & 66 \\
$\geq 31$ years & $20 \%$ & $80 \%$ & $100 \%$ & 37 \\
\hline Total & $46 \%$ & $54 \%$ & $100 \%$ & 191 \\
\hline
\end{tabular}

Figure 3: Time Management Classification by Age Category

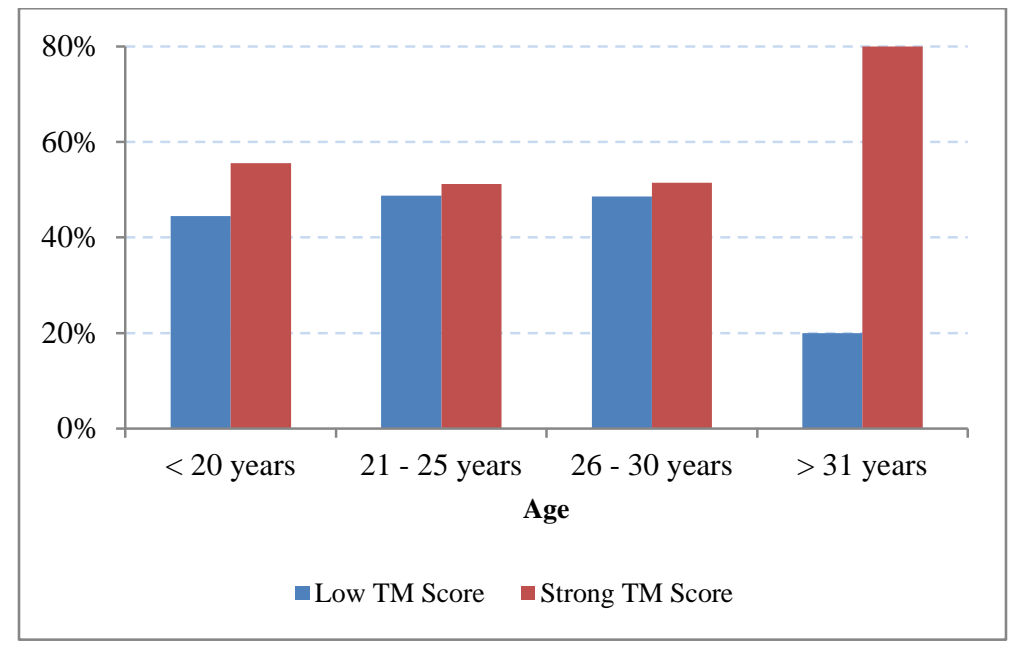

$(n=191)$ 
Table 5: Time Management Classification by GPA

\begin{tabular}{|l|rr|r|r|}
\hline & \multicolumn{2}{|c|}{ TM Score Classification } & & \\
\hline GPA & Low TM Score & Strong TM Score & Total & $\boldsymbol{n}$ \\
\hline 2.5 or less & $43 \%$ & $57 \%$ & $100 \%$ & 14 \\
$2.5-3.0$ & $47 \%$ & $53 \%$ & $100 \%$ & 68 \\
$3.0-3.5$ & $52 \%$ & $48 \%$ & $100 \%$ & 69 \\
$3.5+$ & $34 \%$ & $66 \%$ & $100 \%$ & 38 \\
\hline Total & $46 \%$ & $54 \%$ & $100 \%$ & 189 \\
\hline
\end{tabular}

Note: 2 NR responses are not included

Figure 4: Time Management Classification by GPA

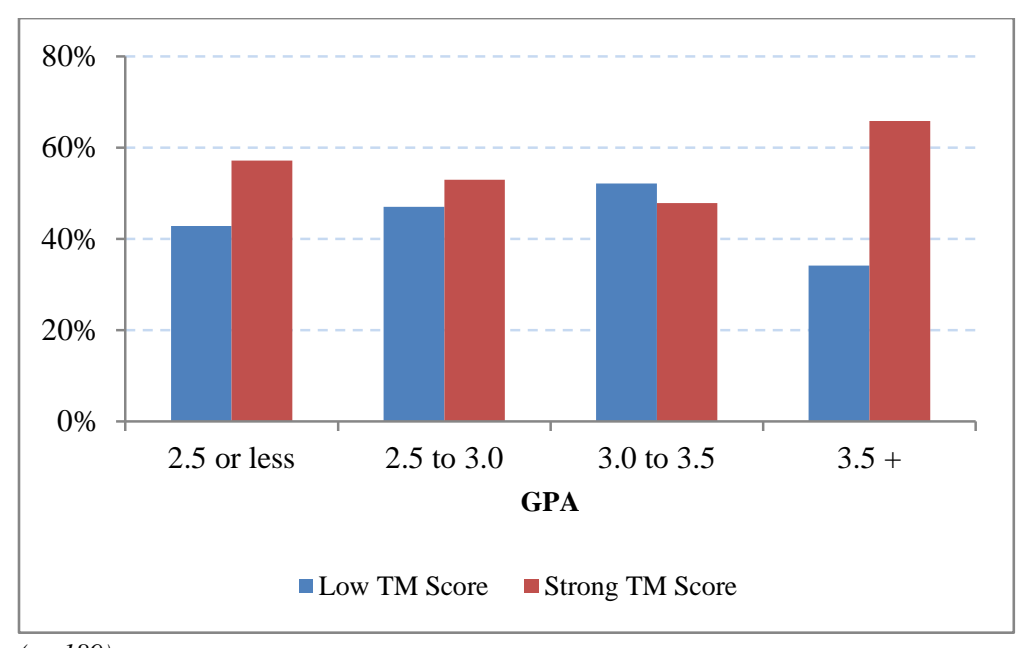

$(n=189)$

Table 6: Time Management Classification by Employment

\begin{tabular}{|c|c|c|c|c|}
\hline & \multicolumn{2}{|c|}{ TM Score Classification } & \multirow[b]{2}{*}{ Total } & \\
\hline Employment & Low TM Score & Strong TM Score & & \\
\hline Employed FT & $51 \%$ & $49 \%$ & $100 \%$ & 74 \\
\hline Employed PT & $44 \%$ & $56 \%$ & $100 \%$ & 71 \\
\hline Student only / not employed & $41 \%$ & $59 \%$ & $100 \%$ & 46 \\
\hline Total & $46 \%$ & $54 \%$ & $100 \%$ & 191 \\
\hline
\end{tabular}


Figure 5: Time Management Classification by Employment

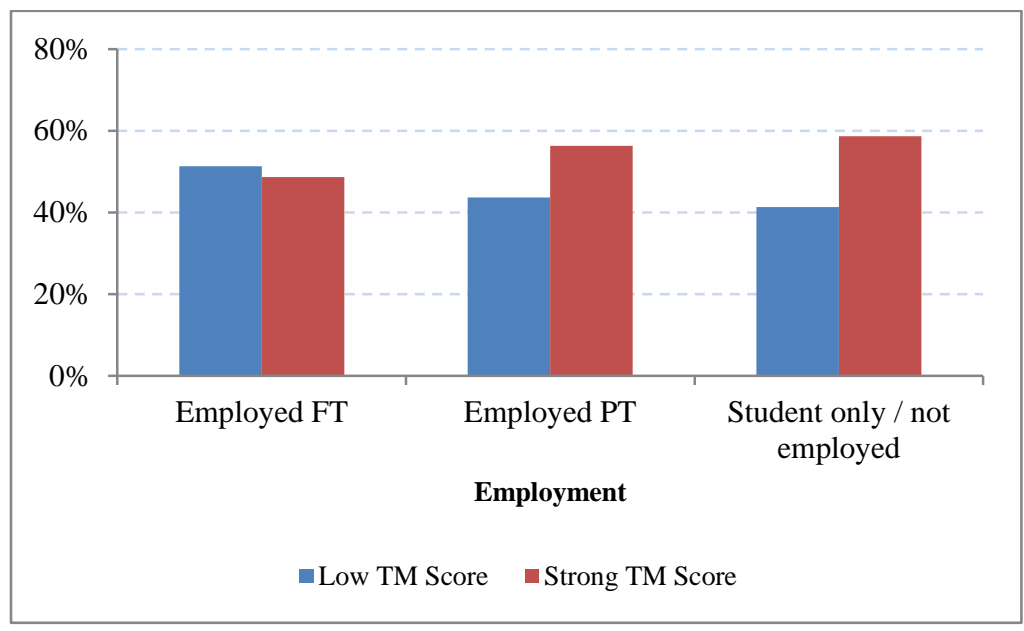

$(n=191)$

A review of the tabulated and visually presented information suggests that, for this sample of students, there may be some relationship between TM score classification and 1) the number of online courses completed by the student, 2) age, 3) the student's gpa, and 4) employment status.

- Among the group of students who have completed 4 or more online course, $57 \%$ have strong TM scores and 43\% have low TM scores. In the other groups a higher percentage of students have low TM scores than have strong TM scores.

- Among older students (at least 31 years of age), more have strong TM scores than low TM scores. In other age categories, there appears to be a more nearly equal division between low and strong TM scores.

- Among the students with the highest GPA, 66\% have strong TM scores while 34\% have low TM scores. Among students with the lowest GPA, 57\% have strong TM scores while 43\% have low TM scores. The unexpected direction of difference at the lower end of the GPA scale perhaps reflects a wider range of TM score values and/or the very small $n$ for this GPA category.

- Among students who are not employed and those who are employed part-time, higher proportions have strong TM scores as opposed to low TM scores. Unexpectedly, among students who are employed full time, a higher proportion has low TM scores.

- Enrollment status does not reflect any difference in the proportion of students with strong versus low TM scores. That is, the frequency of low TM scores is approximately the same as the frequency of strong TM scores for students who enroll in courses on a mostly part-time basis as well as for students who enroll in courses on a mostly full-time basis. 
To explore the relationship between course design features and TM scores, a Use score was calculated to reflect the extent to which students indicated they used various course features including: course objectives, course content (any format), discussion boards, e-mail (with instructor), instructor notices posted in Blackboard Learn, on-campus office hours, and online office hours. A Likert scale was used with a value of 5 meaning daily use and a value of 1 meaning no use; a mean was calculated for each student across use values for the various features. The resulting Use scores had a symmetric distribution. Use scores were classified as Low Use, Moderate Use, and High Use. Low Use scores were those in the lower quartile of the distribution; High Use Scores were those that fell in the upper quartile, and Moderate Use Score were within the interquartile range.

The contingency table (Table 7, based on percentage of row total) and the corresponding Figure 6 reflect the relationship between feature use classification and the TM score classification.

Table 7: TM Classification by Course Feature Use

\begin{tabular}{|l|rr|r|r|}
\hline & \multicolumn{2}{|c|}{ TM Score Classification } & & \\
\hline Use Classification & Low TM Score & Strong TM Score & Total & $\boldsymbol{n}$ \\
\hline Low Use & $65 \%$ & $35 \%$ & $100 \%$ & 48 \\
Moderate Use & $44 \%$ & $56 \%$ & $100 \%$ & 48 \\
High Use & $31 \%$ & $69 \%$ & $100 \%$ & 95 \\
\hline Total & $46 \%$ & $54 \%$ & $100 \%$ & 191 \\
\hline
\end{tabular}

Figure 6: TM Classification by Course Feature Use

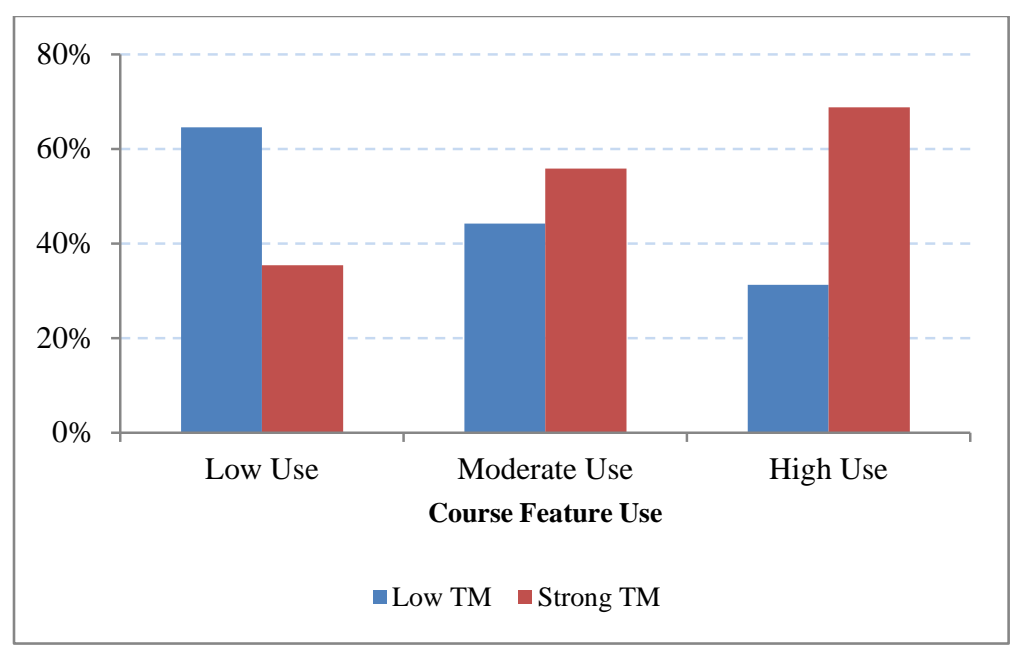

$(n=191)$

Those students who use the course design features that are provided within the course have higher TM scores than those who do not avail themselves of these features; $69 \%$ of these students have strong TM and 31\% have low TM scores. Whereas, among the group of students who have low use of course features, 35\% have strong TM scores and 65\% have low TM scores. 
The difference between proportions of TM scores for the group of moderate use students is not as striking.

The relationship between the use of available course features and the number of completed online course was explored with a contingency table.

Table 8: Course Feature Use Classification by OL Course Completion

\begin{tabular}{|c|c|c|c|c|c|}
\hline & \multicolumn{3}{|c|}{ Use Classification } & & \\
\hline OL Courses Completed & Low Use & Moderate Use & High Use & $\begin{array}{r}\text { Grand } \\
\text { Total }\end{array}$ & $n$ \\
\hline $0-1$ & $38 \%$ & $31 \%$ & $31 \%$ & $100 \%$ & 13 \\
\hline $2-3$ & $16 \%$ & $26 \%$ & $58 \%$ & $100 \%$ & 38 \\
\hline 4 or more & $26 \%$ & $24 \%$ & $49 \%$ & $100 \%$ & 140 \\
\hline
\end{tabular}

Figure 7: Course Feature Use Classification by OL Course Completion

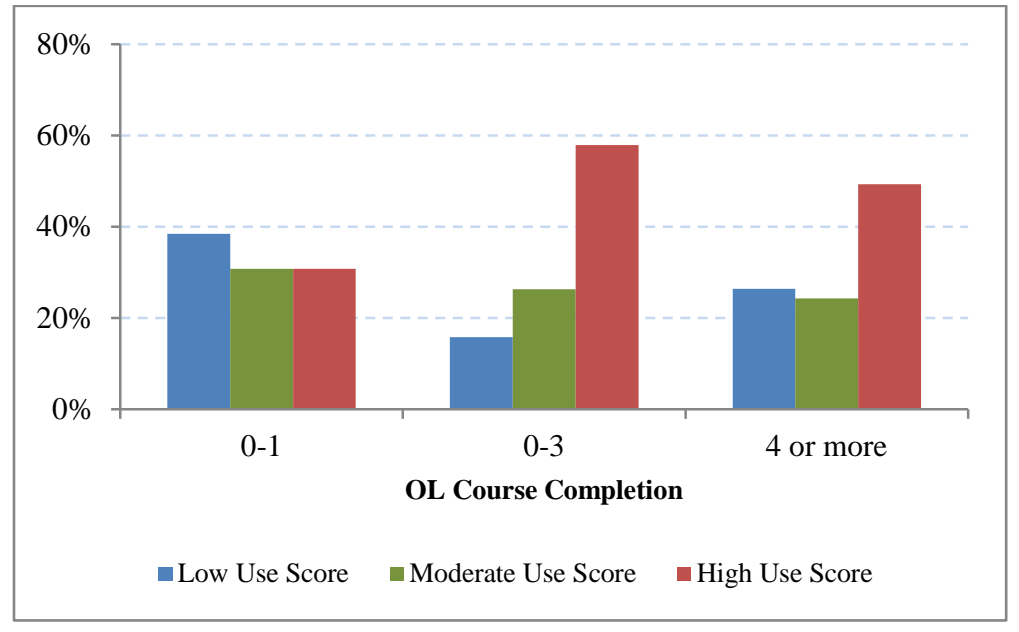

$(n=191)$

Students who completed at least two online courses had high use scores, indicating that those experienced in online availed themselves of the features that were available. There was not much difference in Use scores among the group who had completed 0 or 1 online course.

Open-ended questions asked students to identify time management and/or life-long learning skills they had developed from their online course experiences and from their face-to-face experiences. Responses to these questions revealed beneficial time management approaches from the students' perspective. Some responses noted traditional approaches to time management or life-long learning, while others revealed more creative approaches. Table 8 lists categories of responses that emerged from the responses with examples of responses that fit into each category. 
Table 9: Time Management Strategies Used by Students

\begin{tabular}{|c|c|}
\hline Category of Response & Example Responses in Category \\
\hline \multirow[t]{3}{*}{$\begin{array}{l}\text { 1. Record dates of assignments } \\
\text { and other important course } \\
\text { event information. }\end{array}$} & $\begin{array}{l}\text { - I transfer all data from the online course to my own } \\
\text { planner. I need to write down dates in one place. } \\
\text { Visually, using a daily planner helps me remember } \\
\text { tasks due. }\end{array}$ \\
\hline & $\begin{array}{l}\text { Tools like setting up Google Calendar, with time } \\
\text { ranges to finish something, has worked very well. I } \\
\text { feel that these same skills will prove useful even } \\
\text { after college. }\end{array}$ \\
\hline & $\begin{array}{l}\text { - I set up reminders for assignments, tests and quizzes } \\
\text { on my smartphone. }\end{array}$ \\
\hline \multirow[t]{3}{*}{$\begin{array}{l}\text { 2. Reserve specific times for } \\
\text { study and class preparation. }\end{array}$} & $\begin{array}{l}\text { - From my online classes the time management skills } \\
\text { I have developed include setting time aside usually } \\
\text { 2-3 hours to focus on assignments and upcoming } \\
\text { assignments. Same with lifelong skills. I learned to } \\
\text { set aside time to focus on my online courses as if I } \\
\text { were in an actual classroom. }\end{array}$ \\
\hline & $\begin{array}{l}\text { - One good thing about online class is that we can } \\
\text { work on assignments on our own time schedule. }\end{array}$ \\
\hline & $\begin{array}{l}\text { Every day I look at my agenda planner and write } \\
\text { out exactly what I have to do that day and I } \\
\text { compare it to what has to be done that entire week. }\end{array}$ \\
\hline \multirow[t]{3}{*}{ 3. Follow a study plan } & $\begin{array}{l}\text { I review my schedule weekly - on Sundays - work, } \\
\text { school, and personal. }\end{array}$ \\
\hline & $\begin{array}{l}\text { - I have learned to make sure I understand the online } \\
\text { class format and what is required of me - teaching } \\
\text { myself the material at my own pace. This approach } \\
\text { is preferred for me, and it has taught me to be able } \\
\text { to work independently. }\end{array}$ \\
\hline & $\begin{array}{l}\text { - With online courses I make use of electronic flash } \\
\text { cards to help me study. }\end{array}$ \\
\hline
\end{tabular}




\begin{tabular}{|c|c|}
\hline Category of Response & Example Responses in Category \\
\hline & $\begin{array}{l}\text { - Having to schedule my study time also helps me } \\
\text { manage my time outside of the class. }\end{array}$ \\
\hline 4. Plan ahead & $\begin{array}{l}\text { - My Father died and the convenience of online } \\
\text { helped through the situation - I learned that the } \\
\text { unexpected occurs. }\end{array}$ \\
\hline & $\begin{array}{l}\text { - Do ahead in case technical difficulties arise at the } \\
\text { last minute. }\end{array}$ \\
\hline
\end{tabular}

\section{Summary and Discussion}

In earlier research conducted by the authors, some students suggested that they learned time management skills from participating in online courses ${ }^{1}$. The data compiled here support that student perception since, among the students with the most experience in online courses (4 or more), the percentage of strong TM scores was greater than the percentage of low TM scores (57\% versus $43 \%$ ). It could be argued that many of the students who have completed several online courses may be enrolling in these online courses because of life circumstances that make face-to-face enrollment more difficult; these life circumstances could contribute to better time management skills, a possibility that remains for further investigation.

The study revealed some expected results. One expectation was that a higher proportion of students with the highest of GPAs (3.5 and above) would have strong TM skills rather than low TM skills, and the study results showed this. Among those with at least a 3.5 GPA, there were $66 \%$ with strong versus 34\% low TM scores. It is possible that behaviors associated with good TM skills result in better grades, a notion that is supported in some of the background literature ${ }^{8-}$ 11 .

Another variable that may be an indicator of students' use of TM skills is employment status. Students employed full-time had lower TM scores than those who were employed part-time or were not employed. Full-time employment introduces factors such as job related stress, nonacademic priorities, the potential for over-commitment, and economic issues, all of which must be balanced with course work. TM behaviors can represent additional time-consuming activities; many fully-employed students may perceive that they do not have time for the effort required for tasks that are particularly important in online classes, such as keeping a planner up-to-date and blocking time to study.

It also appears that a maturation factor may influence time management skills. The data with respect to age supports this notion as a very high proportion of the oldest students had strong TM scores versus low TM scores (80\% versus 20\%). The argument that maturation is the strongest influencing factor with respect to students exhibiting effective time management skills is plausible and could be the subject of further research. 
Use of course features (orientation materials, course calendar, course requirements description, objectives, course content (in any format), discussion boards, email with the instructor, instructor notices, on campus office hours, and online office hours) relate to TM scores. The frequency of use of the course design features that are present (particularly in online and hybrid courses) seems to influence TM scores. The Use score was a measure of use frequency with respect to the various course features studied. For students with high Use scores, a greater proportion had strong TM scores, and for students with low Use scores, a greater proportion has low TM scores. Specifically, 69\% of the students who frequently use specific course features have strong TM scores, and 31\% have low TM scores. Whereas, among the students who have low use of course features, 35\% have strong TM scores and 65\% have low TM scores. Effective structuring of these course elements by the instructor may promote more effective time management and enhance the potential for course success.

Student responses to open ended questions not only reflected traditional approaches to TM but reflected use of technology to assist in the endeavor. Students reported using tools such as Google Calendar, Smart Phones, and electronic flash cards.

Thus, the results of this study suggest that relationships do exist between students' time management behaviors, development of time management skills, and the design of online courses. Some appear to be straightforward and expected and others appear to be more complex. In order to promote enhanced student performance in online course, continued study of these relationships is merited.

\section{References}

1. Goodson, C., S.L. Miertschin, and B.L. Stewart, On-line delivery of courses: What components are important to students? Computers in Education Journal, 2012. 3(1): p. 47-58.

2. Miertschin, S.L., C.E. Goodson, and B.L. Stewart, Managing time in on-line courses: Student perceptions. Computers in Education Journal, 2013. 4(2): p. 101-112.

3. Goodson, C., S.L. Miertschin, and B.L. Stewart, Design of on-line courses: Implications for student time management. Computers in Education Journal, 2015. 6(2): p. 92-105.

4. Taylor, F.W., The Principles of Scientific Management. 1913, New York: Harper \& Brothers.

5. Bond, M.J. and N.T. Feather, Some correlates of structure and purpose in the use of time. Journal of Personality and Social Psychology, 1988. 55(2): p. 321-329.

6. Burt, C.D.B. and S. Kemp, Construction of Activity Duration and Time Management Potential. Applied Cognitive Psychology, 1994. 8(2): p. 155-168.

7. Chang, A. and L.T. Nguyen, The mediating effects of time structure on the relationships between time management behaviour, job satisfaction, and psychological well-being. Australian Journal of Psychology, 2011. 63(4): p. 187-197.

8. Barnard, L., V. Paton, and W. Lan, Online self-regulatory learning behaviors as a mediator in the relationship between online course perceptions with achievement. International Review of Research in Open \& Distance Learning, 2008. 9(2): p. 1-11.

9. Britton, B.K. and A. Tesser, Effects of time-management practices on college grades. Journal of Educational Psychology, 1991. 83(3): p. 405-410.

10. Eilam, B. and I. Aharon, Students' planning in the process of self-regulated learning. Contemporary Educational Psychology, 2003. 28(3): p. 304-334. 
11. Forbus, P., J.J. Newbold, and S.S. Mehta. A study of non-traditional and traditional students in terms of their time management behaviors, stress factors, and coping strategies. in Allied Academies International Conference: Proceedings of the Academy of Educational Leadership (AEL). 2010: Dreamcatchers Group, LLC.

12. Macan, T.H., Time management: Test of a process model. Journal of Applied Psychology, 1994. 79(3): p. 381391.

13. Strongman, K.T. and C.D.B. Burt, Taking breaks from work: An exploratory inquiry. Journal of Psychology, 2000. 134(3): p. 229-42.

14. Sabelis, I., Time management: Paradoxes and patterns. Time \& Society, 2001. 10(2-3): p. 387-400.

15. Vodanovich, S.J. and H.M. Seib, Relationship between time structure and procrastination. Psychological Reports, 1997. 80(1): p. 211.

16. Koolhaas, M.J., K. Sijtsma, and R. Witjas, Time perspectives in time management training programs. Gedrag en Organisatie, 1992. 5(2): p. 94-106.

17. Francis-Smythe, J.A. and I.T. Robertson, On the relationship between time management and time estimation. British Journal of Psychology, 1999. 90(3): p. 333.

18. King, A.C., R.A. Winett, and S.B. Lovett, Enhancing coping behaviors in at-risk populations: The effects of time-management instruction and social support in women from dual-earner families. Behavior Therapy, 1986. 17(1): p. 57-66.

19. Macan, T.H., et al., College students' time management: Correlations with academic performance and stress. Journal of Educational Psychology, 1990. 82(4): p. 760-768.

20. Slaven, G. and P. Totterdell, Time management training: does it transfer to the workplace? Journal of Managerial Psychology, 1993. 8: p. 20-8.

21. Jex, S.M. and T.C. Elacqua, Time management as a moderator of relations between stressors and employee strain. Work \& Stress, 1999. 13(2): p. 182-191.

22. Williams, K. (2011) Tips on effective time management. Ohio State University Fact Sheet - Small Business Series.

23. Griffiths, R.F., Time management in telework and other autonomous work environments. 2003, Kansas State University: Ann Arbor. p. 145-145 p.

24. Hall, B.L. and D.E. Hursch, An evaluation of the effects of a time management training program on work efficiency. Journal of Organizational Behavior Management, 1982. 3(4): p. 73-96.

25. Kaufman-Scarborough, C. and J.D. Lindquist, Time management and polychronicity: Comparisons, contrasts, and insights for the workplace. Journal of Managerial Psychology, 1999. 14(3/4): p. 288-312.

26. Donaldson-Feilder, E., J. Yarker, and R. Lewis, Preventing Stress in Organizations: How to Develop Positive Managers. 2011, Chichester, West Sussex: John Wiley \& Sons Ltd. 270.

27. Lay, C.H. and H.C. Schouwenburg, Trait procrastination, time management, and academic behavior. Journal of Social Behavior and Personality, 1993. 8(4): p. 647.

28. Shepperd, R.S., Predictors of Student s\Success in Distance Education Courses, in College of Human Resources and Education. 2002, Dissertation submitted to West Virginia University: Morgantown, WV.

29. Woolfolk, A.E. and R.L. Woolfolk, Time management: An experimental investigation. Journal of School Psychology, 1986. 24(3): p. 267-275.

30. Van Eerde, W., Procrastination at work and time management training. Journal of Psychology, 2003. 137(5): p. 421-434.

31. Adamson, B.J., T. Covic, and M. Lincoln, Teaching time and organizational management skills to first year health science students: does training make a difference? Journal of Further \& Higher Education, 2004. 28(3): p. 261-276.

32. Kisa, A. and K. Ersoy, The Need for Time Management Training Is Universal: Evidence from Turkey. Hospital Topics, 2005. 83(1): p. 13-19.

33. Green, P. and D. Skinner, Does time management training work? An evaluation. International Journal of Training \& Development, 2005. 9(2): p. 124-139.

34. Häfner, A. and A. Stock, Time Management Training and Perceived Control of Time at Work. Journal of Psychology, 2010. 144(5): p. 429-447.

35. Macan, T.H., Time-management training: Effects on time behaviors, attitudes, and job performance. Journal of Psychology, 1996. 130(3): p. 229.

36. Claessens, B.J.C., et al., A review of the time management literature. Personnel Review, 2007. 36(2): p. 255276. 
37. MacCann, C., G.J. Fogarty, and R.D. Roberts, Strategies for success in education: Time management is more important for part-time than full-time community college students. Learning and Individual Differences Journal, 2012. 22(5): p. 618-623.

38. UCLA Statistical Consulting Group. What does Cronbach's alpha mean? Accessed January 12, 2015. Available from: http://www.ats.ucla.edu/stat/spss/faq/alpha.html.

39. Bulmer, M.G., Principles of Statistics. 1979: Dover Publications, Inc. 